\title{
Nuevas miradas sobre los murales del convento agustino de Malinalco. Nueva España, siglo XVI
}

\section{Gisela von Wobeser ${ }^{1}$}

Recepción: 8 de marzo de 2018 / Aceptación: 10 de julio de 2018

\section{Resumen}

En el presente artículo se propone revisar las interpretaciones que a la fecha existen sobre los murales del claustro bajo del convento agustino de Malinalco (México), realizados por indígenas en el siglo XVI, mediante la técnica de la grisalla. En él se rebate la idea de que lo representado es el paraíso celestial o el paraíso terrenal y se sugiere que el programa iconográfico se centra en los 12 escudos monumentales, alusivos a los nombres de Jesús, de María y al emblema de la orden agustina. Asimismo, se destaca la importancia ornamental de los motivos fitomorfos y zoomorfos que acompañan los escudos y que predominan visualmente dentro del conjunto. Se señala que las fuentes para la realización de los distintos motivos que componen los murales son muy diversas y provienen tanto de Europa, de códices americanos y del entorno natural de Malinalco. Finalmente se analiza el friso epigráfico y se sugiere que la principal finalidad de los murales fue alabar a Dios, con la esperanza de la salvación eterna.

\section{Palabras clave}

Monogramas; flora; fauna; pintura mural; devociones católicas

\section{Abstract}

The present article proposes to revise the interpretations that to date exist about the murals of the under cloister of the Augustinian convent of Malinalco (Mexico), made by indigenous people in the 16th century, by means of the grisaille technique. In it, the idea of representing the heavenly paradise or the earthly paradise is refuted, and it is suggested that the iconographic program focuses on the 12 monumental shields, alluding to the names of Jesus, Mary and the emblem of the Augustinian order. Likewise, the ornamental importance of the phytomorphic and zoomorphic motifs that accompany the shields and that dominate visually within the group is highlighted. It is noted that the sources for the realization of the different motifs that make up the murals are very diverse and come from Europe, American codices and the natural environment of Malinalco. Finally, the epigraphic frieze is analyzed, and it is suggested that the main purpose of the murals was to praise God, with the hope of eternal salvation.

1 Mexicana. Doctora en Historia por la Universidad Nacional Autónoma de México (UNAM). Docente de la Facultad de Filosofía y Letras e investigadora del Instituto de Investigaciones Históricas, ambas instancias de la UNAM. Correo electrónico: gisela@unam.mx 


\section{Keywords}

Monogram; flora; fauna; mural painting; catholic devotions

\section{Resumo}

O presente artigo propõe revisar as interpretações elaboradas até hoje sobre os murais do claustro do convento agostiniano de Malinalco (México), feito por indígenas no século XVI, através da técnica de grisaille. Para tanto, refuta-se a ideia de representar o paraíso celestial ou terrestre e sugere-se que o programa iconográfico se centra nos 12 escudos monumentais alusivos ao emblema da ordem agostiniana e aos nomes de Jesus e de Maria. Destaca-se também a importância ornamental dos motivos fitomórficos e zoomórficos que acompanham os escudos e predominam visualmente dentro do conjunto. Cabe assinalar que as fontes para a realização dos diferentes motivos que compõem os murais são muito diversas e vêm da Europa, de códices americanos e do ambiente natural de Malinalco. Finalmente, analisa-se o friso epigráfico e sugere-se que o objetivo principal dos murais foi louvar a Deus com a esperança da salvação eterna.

\section{Palavras chave}

Monograma; flora; fauna; pintura mural; devoções católicas

Noventa y cinco kilómetros al suroeste de la ciudad de México, en la localidad de Malinalco, Estado de México, se encuentra el convento agustino de la Transfiguración, cuyo claustro bajo está cubierto de murales del siglo XVI, únicos en su género por los escudos monumentales y motivos de la naturaleza que contienen (Figuras 1, 2 y 3). Los murales destacan por su calidad pictórica, por la enorme extensión que abarcan -unos 825 m2-, y por la densidad del espacio cubierto, un verdadero horror vacui que cubre la totalidad de los cuatro muros y de las cuatro bóvedas (Figura 4).

Figura 1. Vista general del muro norte del Convento de la Transfiguración de Malinalco

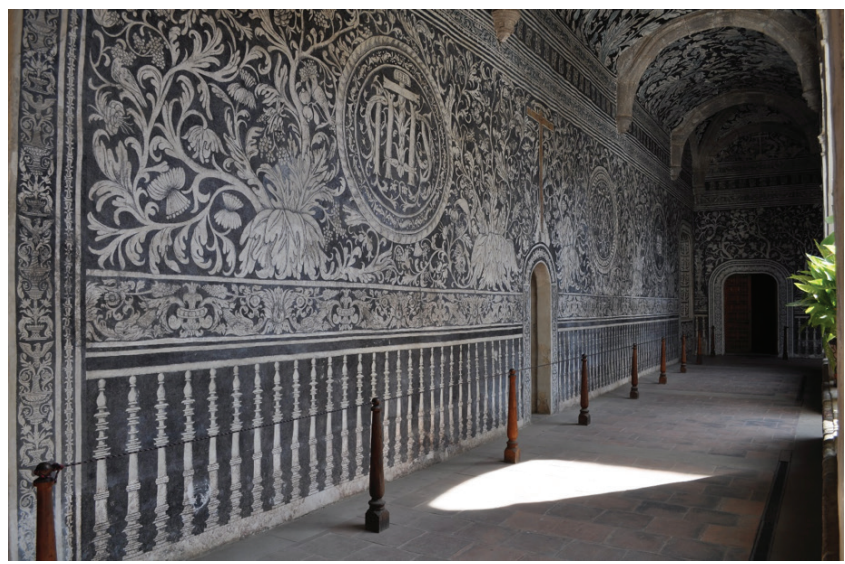


Figura 2. Vista general del muro este del Convento de la Transfiguración de Malinalco

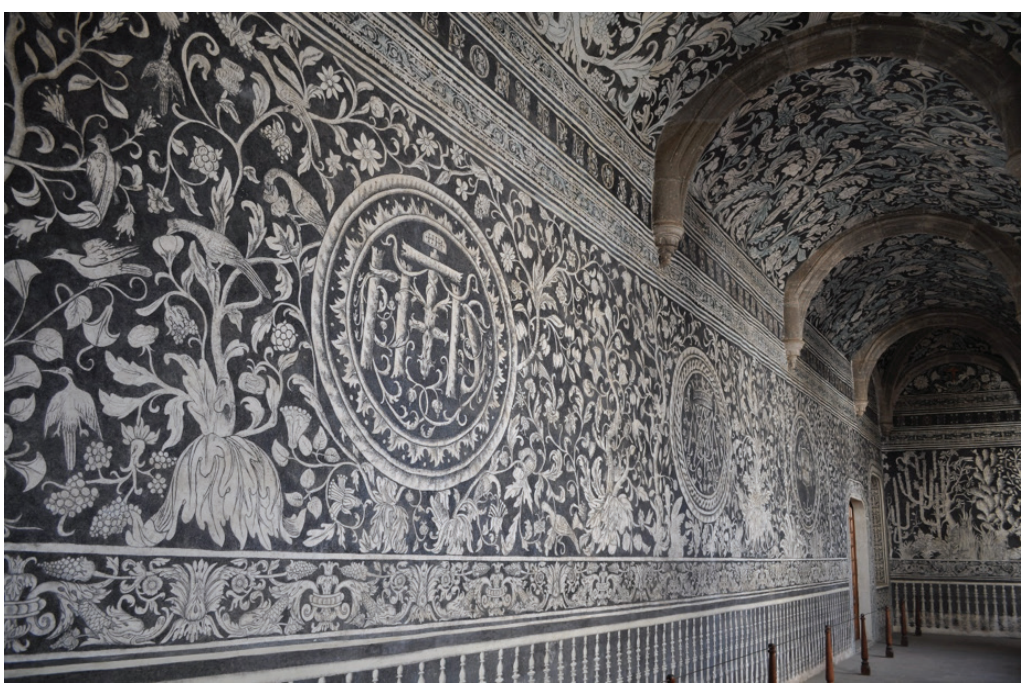

Fuente: von Wobeser, 2017.

Figura 3. Vista general del muro sur del Convento de la Transfiguración de Malinalco

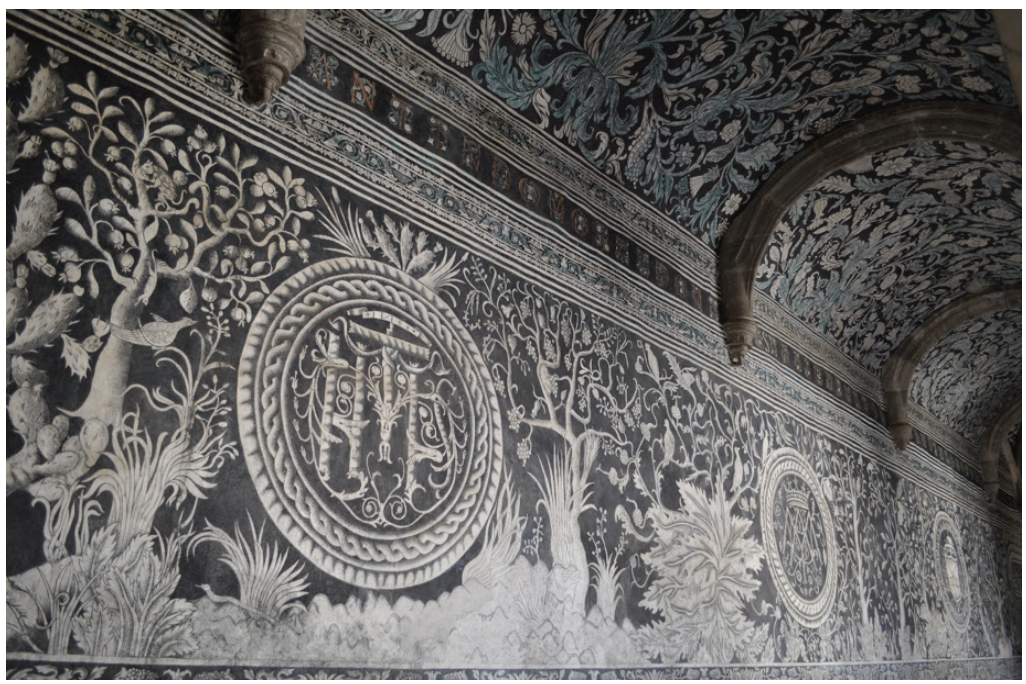

Fuente: von Wobeser, 2017. 
Figura 4. Vista general del muro oeste del Convento de la Transfiguración de Malinalco con la intervención posterior del acceso a la escalera que conduce hacia el claustro alto

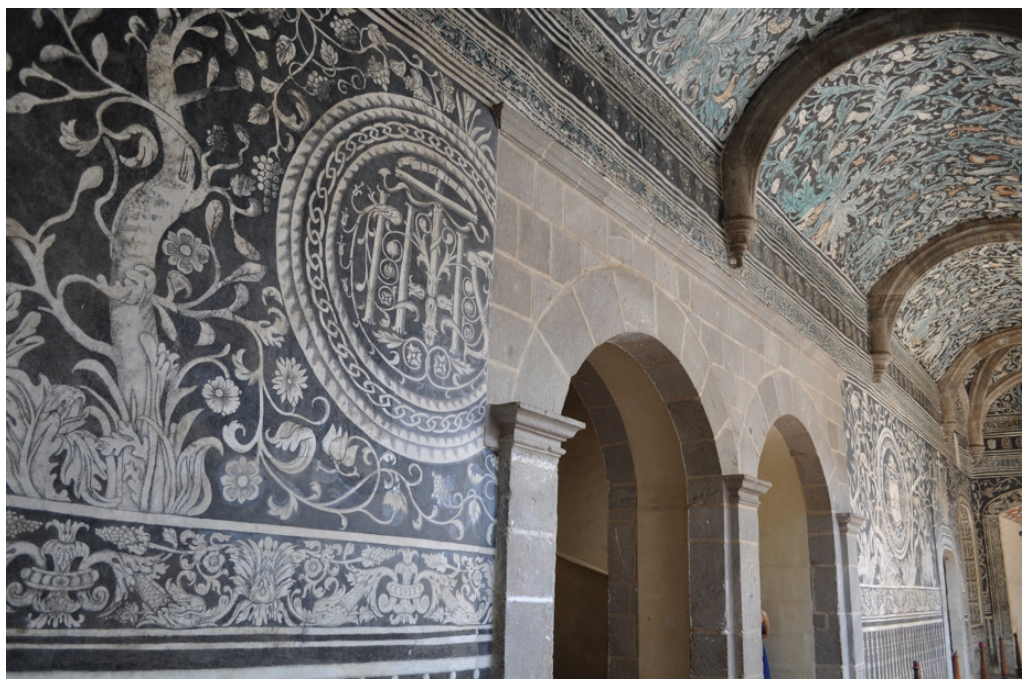

Fuente: von Wobeser, 2017.

Malinalco perteneció en la época virreinal a la cabecera de Ocuilan, región en la que evangelizaron los agustinos, quienes, en el siglo XVII, patrocinaron el famoso santuario del Señor de Chalma, situado en las inmediaciones. La construcción del conjunto conventual de Malinalco inició hacia 1540, unos siete años después del arribo de la orden a Nueva España, y se prolongó a lo largo de todo el siglo. Hacia el último tercio, los muros de Malinalco se cubrieron con pinturas murales, como fue habitual en los conventos de la época. Además de los mencionados murales del claustro bajo, se realizaron otros en la sacristía, el refectorio y la sala de profundis, de la cual actualmente solo quedan algunos fragmentos en mal estado de conservación (las pinturas del pórtico, de la escalera y del claustro alto, así como de las pilastras del claustro bajo son posteriores y no abordan la temática de la naturaleza, por lo cual no se incluyen en este estudio). Años después los murales se encalaron, sin que sepamos la razón de ello. Esto permitió su buena conservación, ya que se mantuvieron ocultos hasta que se descubrieron en 1937. A partir de 1940, se sometieron a diferentes fases de restauración, la última de las cuales se llevó a cabo en 2001, bajo la cuidadosa supervisión del restaurador Manuel Serrano (Pineda Servín, 2018, p. 5; White y Zepeda, 2005, pp. 15-16). Lamentablemente no hay registros confiables de las anteriores intervenciones, lo que dificulta la interpretación de algunos elementos de los murales, ya que no se sabe si hubo añadidos y/o alteraciones. 


\section{La composición pictórica de los murales}

En el siglo XVI, los frailes agustinos no escatimaron recursos para lograr espacios conventuales de gran belleza arquitectónica, provistos de pinturas murales muy bien ejecutadas, que cubrían amplias áreas, como puede observarse en los de Actopan, Epazoyucan, Acolman y Malinalco, para solo citar algunos ejemplos. Además del gran valor artístico de la mayoría de estos murales, son muy importantes por su significado litúrgico.

Los murales del claustro bajo del convento de Malinalco abarcan las cuatro paredes y las respectivas bóvedas y están compuestos simétricamente. En las paredes, el espacio pictórico se divide mediante frisos y franjas de distinto grosor, mismas que se prolongan alrededor de los cuatro muros, lo que les da continuidad, orden y armonía. En el nivel inferior, a manera de guardapolvo, arranca una balaustrada, pintada en color blanco sobre fondo negro. Es seguida de dos líneas blancas, sobre las cuales hay una cenefa con grutescos, formada por elementos decorativos que parecen peces, hojas de acanto y flores. Encima de esta, al centro y a la altura de los ojos del espectador, está el friso principal, que comprende un metro y tres centímetros de altura. Este contiene 11 escudos de gran formato (uno se perdió al construirse la escalera que conduce al claustro alto) con monogramas de Jesús, conformado por las letras IHS (Figura 5); de María integrado por las letras MA y de la orden de san Agustín (Figuras 5, 6 y 7). Tanto el número y la secuencia de los escudos (primero el de Jesús, después el de María y por último el de los agustinos), así como su lugar dentro de la composición, se repiten en cada uno de los muros (Figuras 1, 2 y 3). La realización de los tres escudos dedicados al nombre de Jesús, así como los dedicados a María y a la orden agustina es similar, pero varía en cuanto a algunos detalles, así como a los elementos fitomorfos con que están adornados (Figuras 5, 6 y 7). Los escudos están rodeados de una exuberante vegetación conformada por setos de acantos, arbustos y árboles con flores y frutos de diversos tipos, muchos de ellos fantásticos. Entre la vegetación hay algunos animales, en su mayoría aves y mamíferos. Cuatro líneas de color blanco separan esta sección de una segunda cenefa formada por figuras geométricas, encima de la cual, nuevamente separada por otra línea, se encuentra un friso epigráfico, adornadas con motivos florales, que conforman un fragmento del salmo 84, escrito en latín, cuyo texto refiere lo siguiente:

Cor meum et caro mea laudabunt Deum vivitem. Et enim passer invenit Domum et Turtur nidum ubi reponat sibi Pullos suos. Altaria tua domine virtutum Rex meus et Deus meus. Beati qui habitant in domo tua domine. In in secula seculorum laudabunt. [Mi corazón y mi carne cantan al Dios vivo. Aun el gorrión haya casa y la golondrina nido para sí, donde pongan sus polluelos. Entre tus altares, o Yahvé de los ejércitos, Rey mío y Dios mío, bienaventurados los que habitan en tu casa. Perpetuamente te alabarán] (Figura 8). 
Figura 5. Escudo con el emblema de Jesucristo. Convento de la Transfiguración de Malinalco

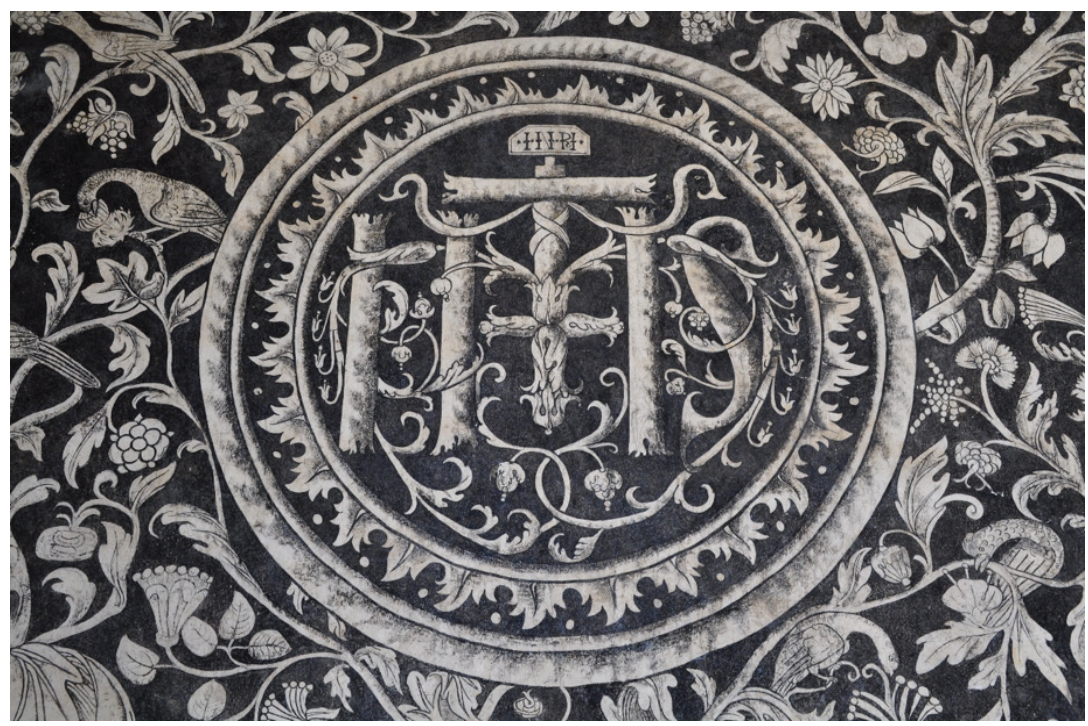

Fuente: von Wobeser, 2017.

Figura 6. Escudo con el emblema de María. Convento de la Transfiguración de Malinalco

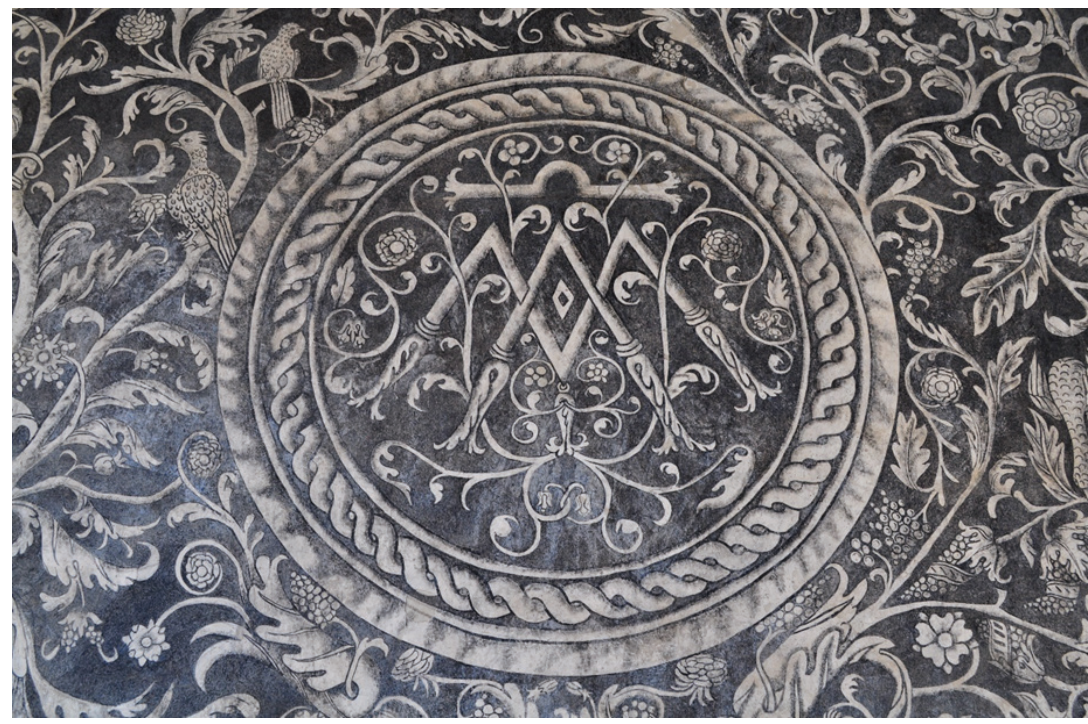

Fuente: von Wobeser, 2017. 
Figura 7. Escudo con el emblema de la Orden de San Agustín.

Convento de la Transfiguración de Malinalco

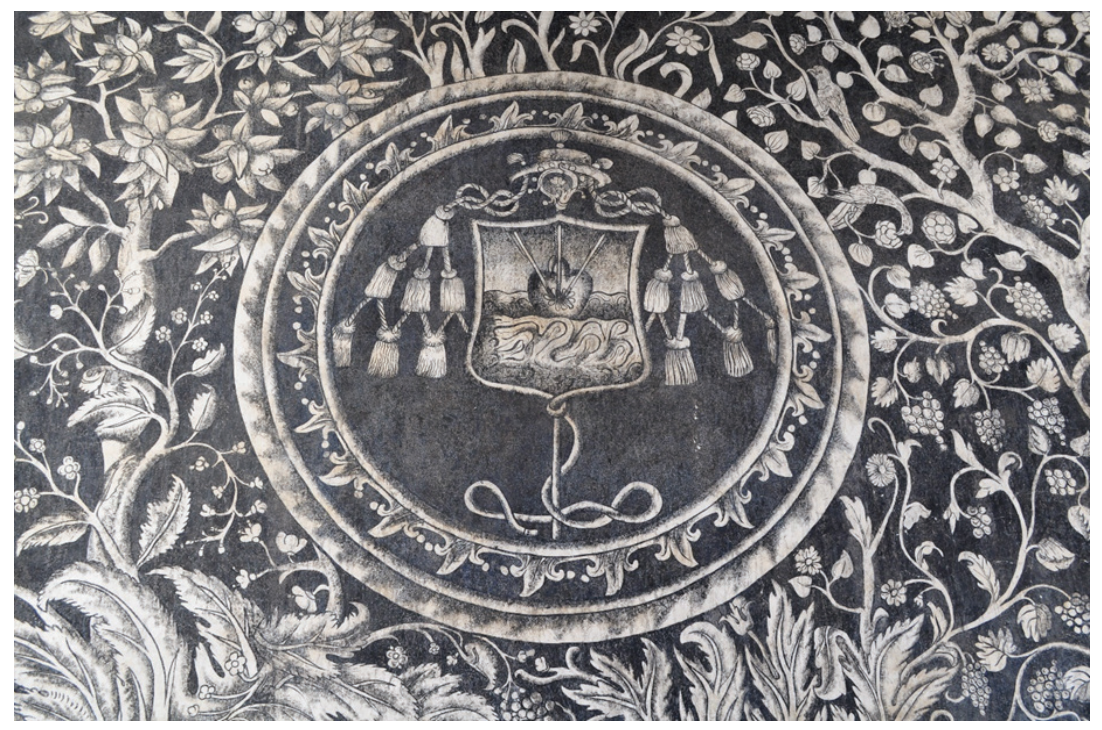

Fuente: von Wobeser, 2017.

Figura 8. Letras del friso superior que componen el inicio del salmo 84: "Cor meum et". Convento de la Transfiguración de Malinalco

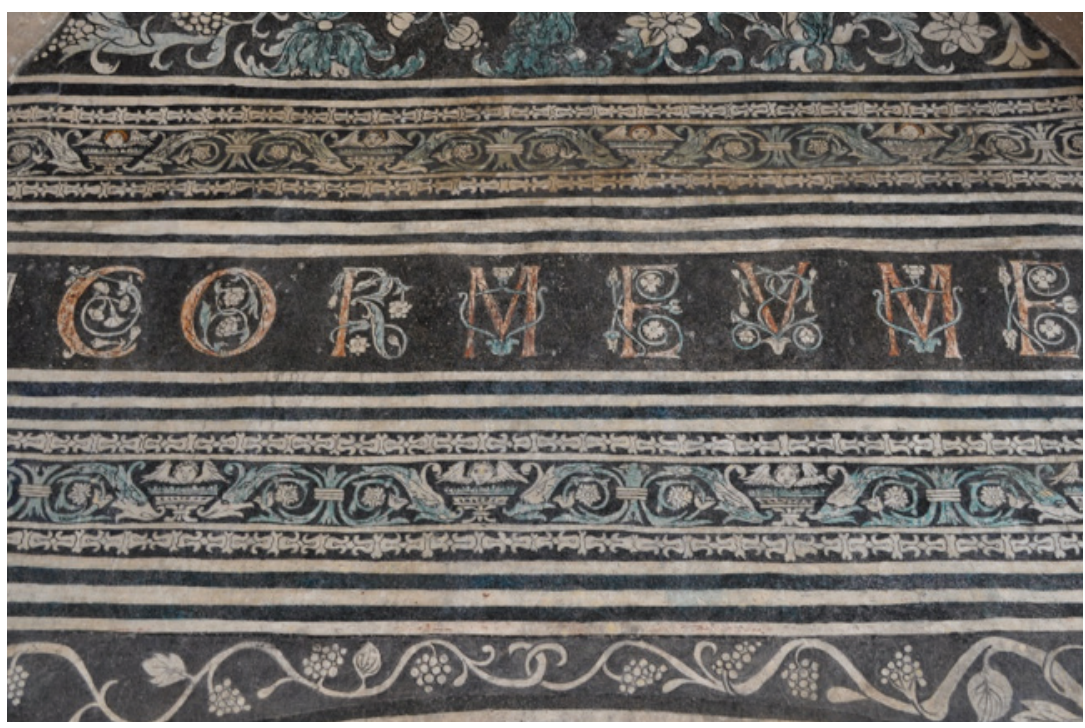

Fuente: von Wobeser, 2017. 
El confesionario, adosado al muro norte, tiene una pintura que representa a un fraile agustino acompañado de una personificación de la muerte, a manera de un esqueleto con guadaña en mano (Figura 9). Las bóvedas están cubiertas con motivos florales, de influencia renacentista flamenca e italiana, en los que predominan los acantos acompañados de ramas, hojas, flores y frutos de distintas especies, en su mayoría fantásticas. Entre el follaje se advierten algunos insectos como abejas y mariposas. A diferencia de los muros, en los que mediante la sobreposición de las figuras se produce la ilusión de perspectiva y de la existencia de diferentes planos de profundidad, aquí cada especie vegetal y animal ocupa su propio espacio (Figura 10).

Figura 9. Fraile agustino con una personificación de la Muerte, en figura de un esqueleto con guadaña en mano. Convento de la Transfiguración de Malinalco

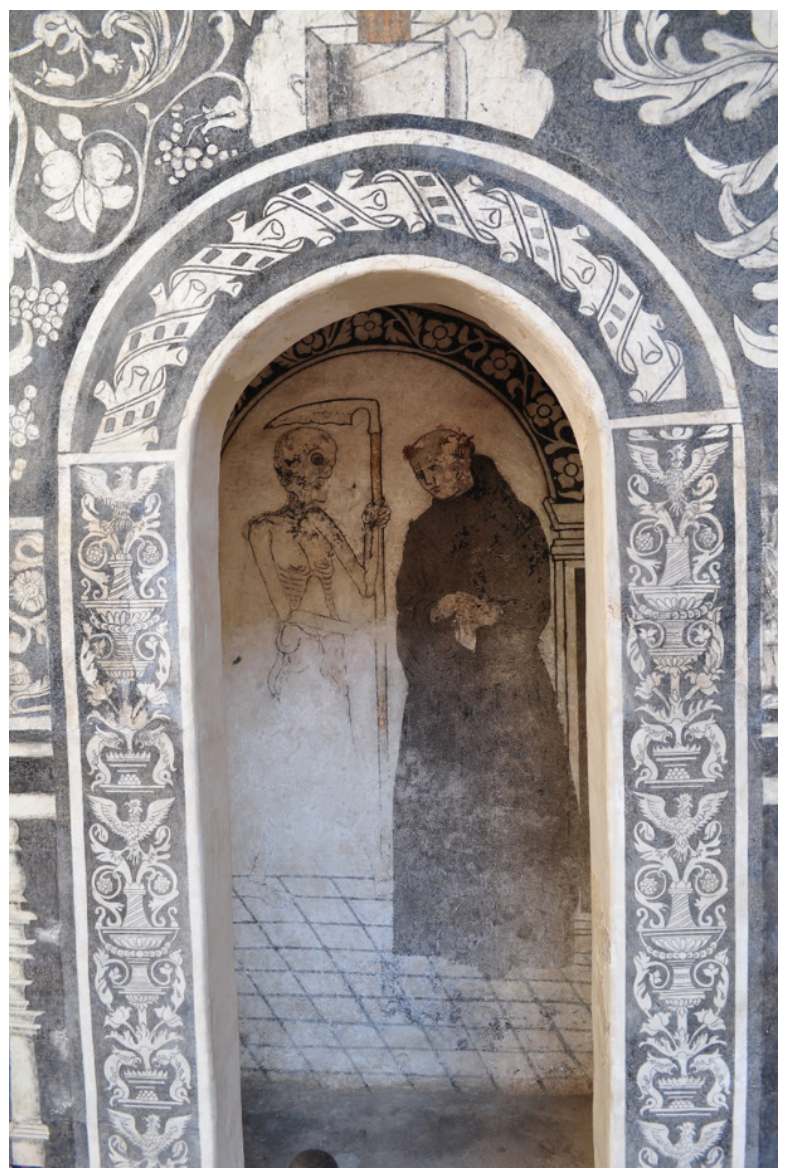

Fuente: von Wobeser, 2017. 
Figura 10. Murales de una de las bóvedas. Convento de la Transfiguración de Malinalco

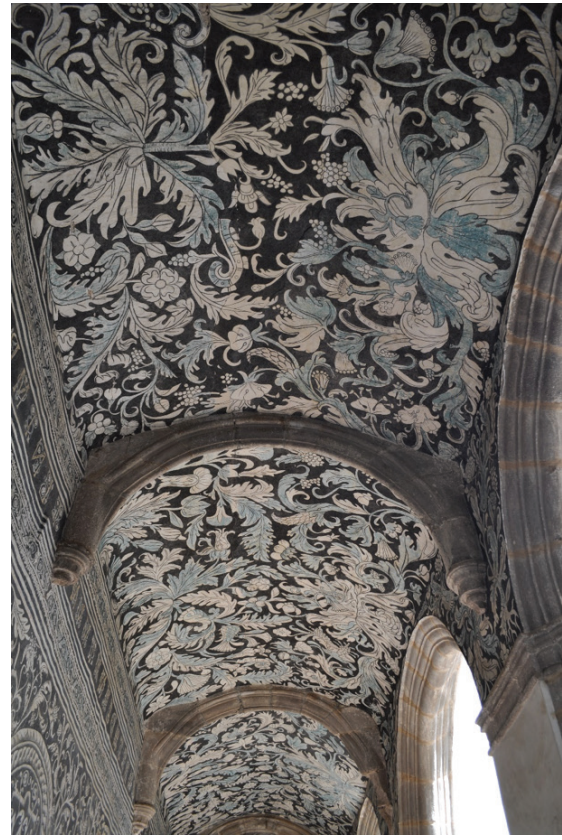

Fuente: von Wobeser, 2017.

\section{La realización de los murales}

Se cree que los ejecutantes de los murales de Malinalco debieron ser indígenas, ya que durante la segunda mitad del siglo XVI había muy pocos pintores europeos activos en Nueva España. Para cubrir la demanda de objetos sagrados para el culto y para la catequesis, franciscanos, dominicos y agustinos fundaron escuelas de artes y oficios en las que enseñaron a los nativos las técnicas pictóricas europeas. La primera y más famosa fue la establecida por el franciscano Pedro de Gante junto al convento de San Francisco de la ciudad de México. Los agustinos fundaron una escuela de Artes y Oficios en su convento de Tiripetío, en Michoacán, que asimismo llegó a tener gran prestigio. Los indígenas resultaron ser muy buenos aprendices y al cabo de pocos años se convirtieron en consumados artistas. El cronista franciscano Gerónimo de Mendieta refiere que después de que vieron las "imágenes de Flandes y de Italia, no hay retablos ni imagen, por prima que sea, que no la retraten y contrahagan" (de Mendieta, 1770, p. 404) y Bernal Díaz del Castillo comparó a los pintores Andrés de Aquino, Juan de la Cruz, y el Crespillo con Apeles, Berruguete y Miguel Ángel (Díaz del Castillo, 1632, citado por Ángeles Jiménez, 2004, pp. 119-120).

Los pintores indígenas trabajaban bajo la supervisión de los frailes y a partir de programas iconográficos diseñados por ellos. Generalmente se basaban en 
grabados impresos en hojas sueltas o contenidos en libros. Según los requerimientos de los concomitantes los copiaban de manera integral o tomaban partes de ellos, mismas que combinaban con imágenes procedentes de otras fuentes. Al parecer, había pintores itinerantes, especializados en pintura mural, que eran contratados por los conventos para realizar los trazos principales en los muros. Después las obras eran terminadas por artistas locales con menos experiencia.

Aunque resulta imposible reconstruir el proceso creativo de los murales de Malinalco, se advierte la intervención de varias manos, algunas más diestras que otras (Peterson, 1993, pp. 50-51). A modo de hipótesis cabe plantear que la ejecución de los frescos pudo haber empezado en el muro norte, el adosado a la iglesia, ya que allí comienza el salmo y en él predominan las especies vegetales y animales europeas, probablemente tomadas de algún tapiz o grabado, y que posteriormente se continuó con los muros este y sur. En estas últimas dos paredes los pintores parecen haber tenido mayor libertad para elegir sus motivos. Así, hay vegetales y animales que remiten al entorno natural del lugar. En el extremo izquierdo del muro sur, hay un conjunto de plantas propias de climas cálidos, inexistentes en el Viejo Continente, pintadas con gran naturalidad, entre las cuales hay cactáceas (órganos), un nopal en flor, un guayabo y un cacaloxóchitl (árbol de flor de mayo) (Figura 12). Algunas pocas imágenes provienen de fuentes americanas. Un ejemplo es el mono araña situado a la izquierda, que se muestra en la Figura 11, tomado del Códice Florentino, como ha demostrado Jeanette Favrot Peterson (1993, pp. 54-55).

Figura 11. Representación de un colibrí y de dos monos araña, en el muro este. Convento de la Transfiguración de Malinalco

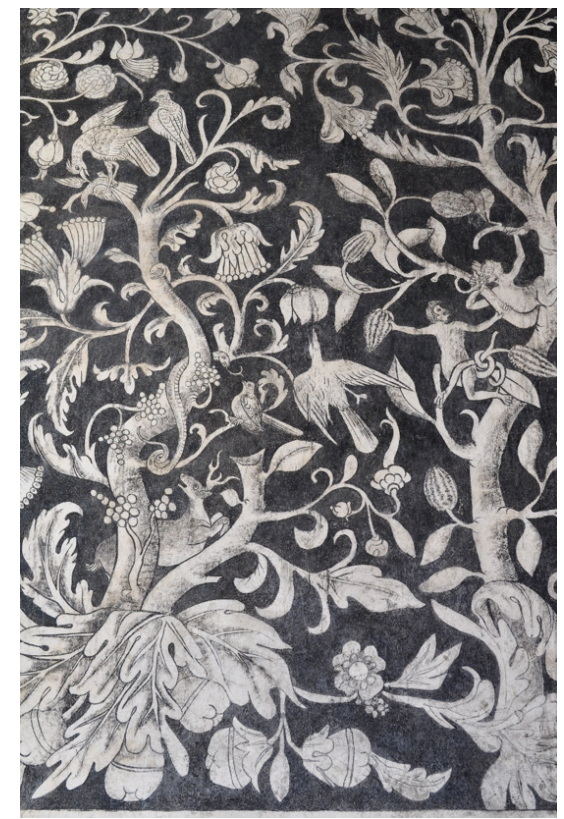


Figura 12. Representación de órganos en floración, de un árbol de cacaloxóchitl, de un nopal y de un guayabo, junto con unas matas de acanto y yerba de malinalli $i$ ?, en el muro sur. Convento de la Transfiguración de Malinalco

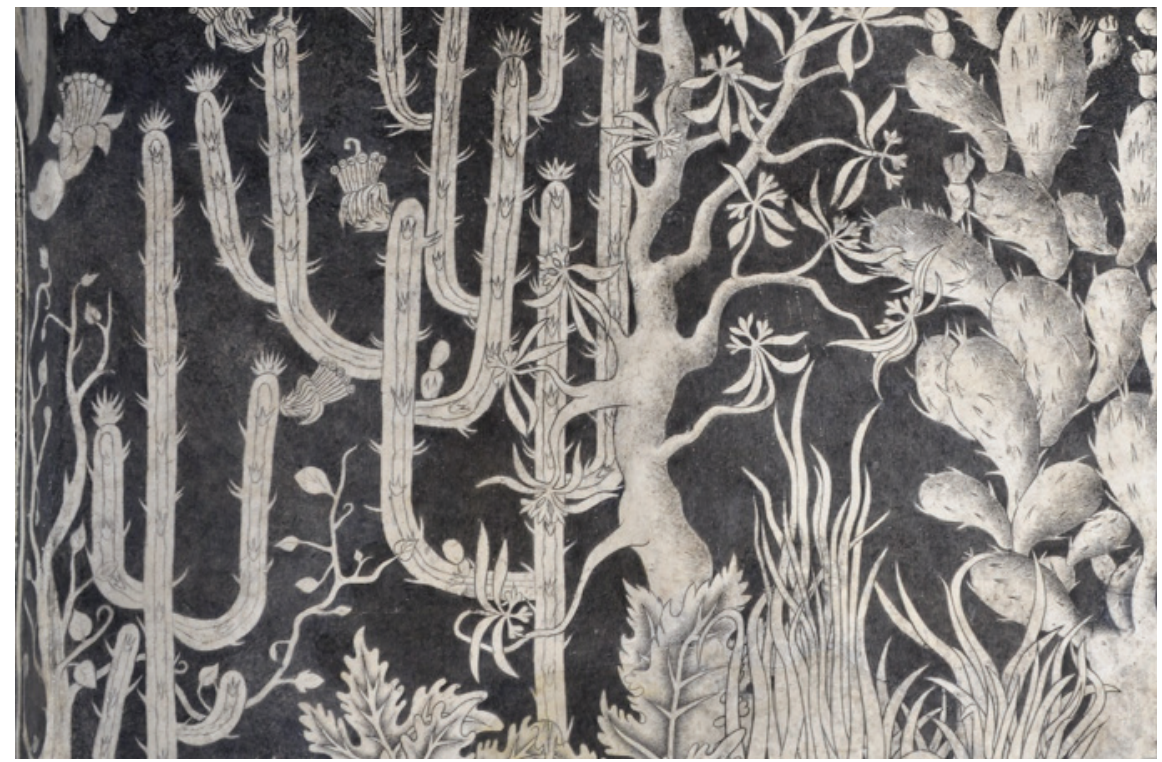

Fuente: von Wobeser, 2017.

La técnica pictórica empleada en Malinalco fue la grisalla², como fue habitual en la pintura conventual novohispana del siglo XVI. Los pigmentos utilizados para realizarla se obtenían al carbonizar vegetales y, por lo tanto, eran de fácil acceso y baratos. Con ellos se obtenían tonos graduados de negros y grises, que destacaban sobre las paredes encaladas. Mediante sombreados y la sobreposición de algunas imágenes se lograban efectos escultóricos y cierta ilusión de perspectiva. Solo en las bóvedas y en las letras que componen el salmo hubo aplicaciones de rojo, verde, azul, anaranjado y amarillo, que probablemente daten de épocas posteriores, ya que en el siglo XVI la pintura mural por lo general fue monocromática (Figuras 8 y 10). No se puede determinar actualmente si las pinturas se realizaron mediante la técnica del "buen fresco", es decir, aplicando la pintura sobre un enlucido recién preparado; si se recurrió al fresco seco, que consistía en dar a la pared una mano de cal y pintar inmediatamente sobre ella, o si se realizaron al temple, sobre una pared seca, mediante la aplicación de un aglutinante, como la baba de nopal.

$2 \quad$ La grisalla (del francés grisaille) es una técnica pictórica monocromática que se utilizó en Europa a partir del siglo XIV. Mediante la aplicación de un claroscuro muy matizado y a través de gradaciones de un solo color (generalmente gris o amarillo oscuro) se logra la sensación de ser un relieve escultórico. 


\section{Las fuentes visuales en las que se basaron los artistas}

Como sucedió con la mayor parte de la pintura religiosa de la época, los murales de Malinalco pertenecen a la tradición europea y tienen una marcada influencia renacentista, flamenca e italiana. Flandes perteneció al Imperio español a raíz de la subida al trono de Carlos $V$, situación que estimuló la inmigración de flamencos, así como el intercambio mercantil entre dicha región y Nueva España. Flandes era un importante centro de producción de obras de arte, de libros y de estampas realizadas mediante grabado en madera.

Como ha demostrado Jeanette Favrot Peterson, el concepto y la composición de los murales provienen de tapices heráldicos flamencos (Peterson, 1993, p. 77). Sabemos que el pintor flamenco Simón Pereyns estuvo trabajando en el retablo mayor de la iglesia del convento de Malinalco y es probable que él haya intervenido en el diseño del programa iconográfico del claustro. Los tapices, entre los cuales los más prestigiados eran los de Flandes, se utilizaban profusamente en Europa durante la época moderna como alfombras, cubrecamas y manteles, para suplir el escaso mobiliario de las casas y los palacios. Las familias nobles y de la alta burguesía solían decorarlos con sus escudos de armas, para dar a conocer los méritos de sus dinastías. A Nueva España llegaron a través de las redes comerciales, o junto con sus propietarios, ya que era costumbre que los viajeros los llevaran consigo. Por ejemplo, el arzobispo fray Juan de Zumárraga aludió, en una carta a Carlos V, al gran número de tapices que había en las casas de los españoles que superaban los que vio en la cámara de la emperatriz (Gerlero, 1981, p. 593).

En particular, los murales de Malinalco son similares a dos tapetes heráldicos flamencos del siglo XVI. El primero es originario de Brujas y representa las armas del obispo de Nocera, Paolo Giovio. Fue realizado hacia 1540-1555, en lana y en seda, y actualmente forma parte de la colección del Victoria and Albert Museum (Peterson, 1993, p. 78). Hay coincidencia entre esta obra y los murales de Malinalco en la colocación de los escudos dentro de la composición, los motivos florales y animales que los circundan y en la cenefa de grutescos (Figura 13). El segundo es el tapiz heráldico de Lewknor, asimismo proveniente de Brujas, realizado en 1564. También aquí hay coincidencia entre los escudos, su dimensión y su colocación en el centro de la composición y el hecho de estar rodeados de elementos vegetales, especialmente de flores, así como en la cenefa que rodea el tapiz, con escudos, acompañados de hojas, flores y frutos (Figura 14). 
Figura 13. Tapete heráldico flamenco con las armas de la familia Giovio, y detalle del mismo. Hacia 1540-1555, Victoria and

Albert Museum (cat. 256-1895)
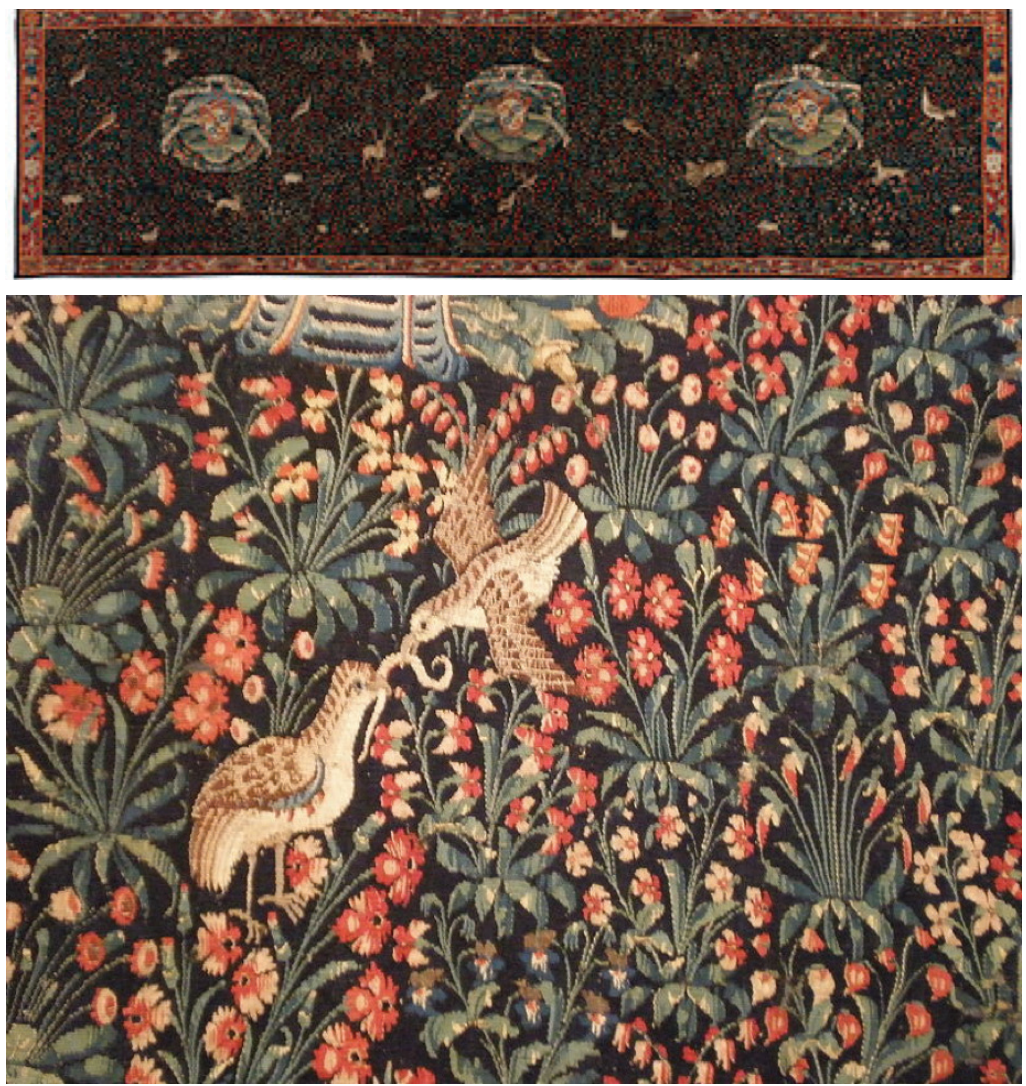

Fuente: von Wobeser, 2017.

Figura 14. Tapete heráldico flamenco de la familia Lewknor, 1564. Clasificación: Textiles-Tapestries Credit Line: Fletche Fund, 1958. Accession Number: 59.33

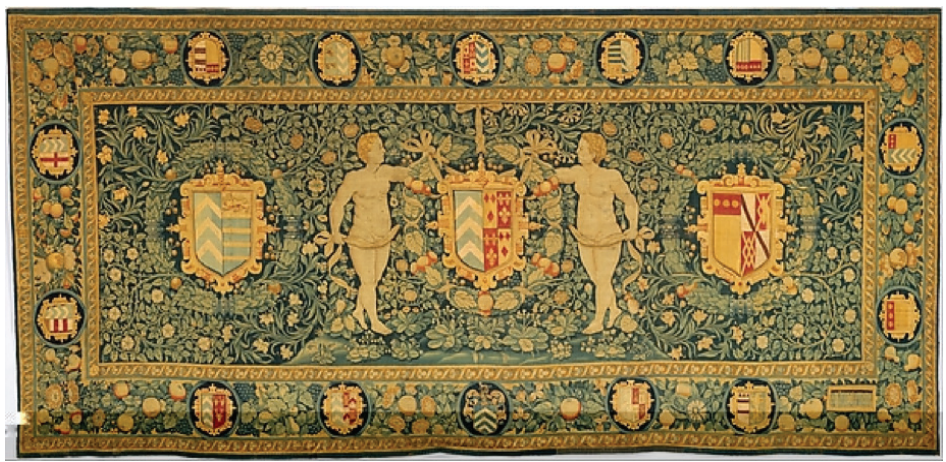

Fuente: von Wobeser, 2017. 
Los motivos fitomorfos y zoomorfos que inundan el espacio pictórico de muros y bóvedas provienen de fuentes diversas. Al parecer, ante el reto de cubrir todo el espacio disponible, los pintores acudieron a todos los modelos que estuvieron a su alcance, lo que dio como resultado una gran variedad de formas que no guardan ninguna proporción entre sí y que remiten a ámbitos culturales distintos. Los frescos del muro norte tienen semejanza con obras renacentistas, tales como los grabados de Agostino Veneziano. Algunos motivos aislados parecen derivar de manuales botánicos como la representación de las flores huacalxóchitl, yolloxóchitl y xiloxóchitl y animales como el búho y el mono araña, que derivan del Códice Florentino (Peterson, 1993, pp. 76-87).

Los pintores asimismo incluyeron plantas y animales americanos, que tomaron directamente del entorno, entre ellos cactáceas, árboles de cacaloxóchitl (flor de mayo), yoloxóchitl (magnolia del sur), de zapote, de tecomaxóchitl (copo de oro) y de xiloxóchitl, frutos de cacao, colibríes, tlacuaches, coyotes y monos araña. Especialmente llamativo resulta un grupo de plantas endémicas de la región de Malinalco, situado en el muro sur, del lado izquierdo, formado por cactáceas y un árbol de guayabo (Figura 12). Finalmente, algunas formas remiten a la pintura prehispánica, como la representación de una abeja y una "vírgula de la palabra", en la bóveda este (Peterson, 1993, p. 94). Así, los murales son testimonio del mestizaje cultural que se dio en el siglo XVI en el seno de los conventos de los frailes evangelizadores.

\section{¿Jardín paradisiaco o naturaleza terrenal?}

Los estudios que hasta la fecha se han ocupado del significado del conjunto pictórico del claustro bajo de Malinalco coinciden en que lo representado es el paraíso. Elena Isabel Estada de Gerlero (1981) plantea que se trata del paraíso celestial, mientras Jeanette Favrot Peterson (1993), así como Laura White Olascoaga y Carmen Zepeda Gómez (2005), sostienen que se trata del paraíso terrenal. Aunque los paraísos terrenal y celestial comparten algunas características, porque la idea del segundo deriva del primero, son lugares distintos del imaginario sobre el más allá.

El paraíso terrenal corresponde al lugar geográfico conocido como Edén, situado sobre la Tierra, donde Dios colocó a Adán y a Eva después de su creación. Desde que estos primeros humanos fueron expulsados del paraíso después de cometer el pecado original, se prohibió a la especie humana la entrada al paraíso. El paraíso está rodeado por todos los flancos por una llama semejante a una espada de doble filo. Se creía que un querubín custodiaba la entrada para impedir el ingreso de seres vivientes o de espíritus (Delumeau, 2003, p. 94). El paraíso terrenal se representó como un frondoso jardín en el que están Adán y Eva desnudos junto al árbol de la fruta prohibida, en ocasiones acompañado de una serpiente que personifica al Demonio. 
Generalmente, se incluye a Dios Padre y en ocasiones al ángel que expulsó a Adán y a Eva del lugar.

El concepto del paraíso celestial deriva del terrenal y se refiere al cielo empíreo.

Frente al trauma de haber perdido la condición ideal prevista por Dios para los humanos en el momento de su creación, primero los judíos y después los cristianos soñaron con recuperar el paraíso perdido, que les permitiría escapar de los trabajos, penalidades y sufrimientos a los que Dios había condenado a los hombres después de expulsar a Adán y a Eva del Edén, por haber comido la fruta del árbol prohibido. Esta añoranza de una mejor vida llevó a identificar el paraíso con el cielo (Wobeser, 2015, p. 83).

En Europa, al paraíso celestial se le representó como un jardín, pero poblado de ángeles, bienaventurados y con la presencia de la Trinidad, de la Virgen María y de los santos. Estos elementos, por ejemplo, están presentes en el célebre Juicio Final de Fra Angélico, pintado hacia 1425, o en obras de Giovanni di Paolo, realizadas hacia 1445 (Mc. Dannell y Lang, 2001, pp. 264267). Ciertamente la abundante vegetación de los frescos de Malinalco evoca un lugar "paradisiaco", de acuerdo con el uso coloquial que actualmente damos a este término. Sin embargo, a mi parecer, el conjunto pictórico carece de elementos iconográficos que permitan identificarlo como paraíso terrenal o como paraíso celestial.

En el siglo XVI, en Nueva España el cielo generalmente se representó como empíreo, situado en lo alto y formado por nubes, con la presencia de, por lo menos, alguna de las siguientes figuras: Dios Padre, Jesucristo, el Espíritu Santo, la virgen María, los santos, los ángeles y los bienaventurados. Ejemplos de la misma época los encontramos en la representación del Juicio final del frontispicio de la capilla abierta del convento agustino de San Nicolás de Tolentino de Actopan (situado en el actual estado de Hidalgo) y de la portería de Santa María Magdalena de Cuitzeo (Michoacán). Este cielo está formado por nubes y presidido por Dios, como supremo juez, entronizado en un arco iris y acompañado por ángeles y bienaventurados. Estos últimos están sentados sobre nubes mientras gozan de la visión beatífica. El cielo como paraíso celestial aparece mencionado en las obras literarias y doctrinales de la época, pero a diferencia de la tradición europea, en Nueva España no hay representaciones plásticas del mismo (Wobeser, 2015, pp. 78-85).

En el estudio pionero "El sentido simbólico-litúrgico en los murales del claustro del convento agustino de la Purificación y San Simón de Malinalco", aparecido en 1981, Elena Isabel Estada de Gerlero quiere ver en los elementos naturales de los murales una representación del paraíso celestial. Parte de la "tradicional creencia doctrinal de que la Iglesia es prefigura de la Jerusalén celeste" y que "este sentido tipológico es igualmente aplicable al claustro" (Gerlero, 1981, p. 567). Fundamenta su idea de que "el signo litúrgico del claustro corresponde al Paraíso celeste" mediante una cita de la obra Rationale Divinorum de Durandus. Con base en san Agustín y san 
Buenaventura, adjudica a las cuatro paredes del claustro una connotación simbólica y las relaciona con las virtudes cristianas (Gerlero, 1981, pp. 582583). Ciertamente en Nueva España privaba la idea de que los conventos eran una extensión del paraíso celestial, pero esto era válido para todos ellos y, por lo tanto, no aporta nada específico a la interpretación de los frescos malinalquenses. La única referencia concreta que da es que "el árbol de la vida" está representado por la cruz que está sobre la entrada del confesionario, pero este tradicionalmente forma parte de la idea del paraíso terrenal y no del celestial (Gerlero, 1981, p. 581).

Jeanette Favrot Peterson plantea en The paradise garden murals of Malinalco. Utopia and empire in sixteenth-century Mexico que se trata del paraíso terrenal. Para identificarlo parte de representaciones del Edén medievales y del Renacimiento en que aparecen de manera separada los dos árboles: "el de la sabiduría" y "el de la vida"; mencionados en el tercer capítulo del Génesis. El primero corresponde al de la fruta prohibida del cual comieron Adán y Eva y el segundo se menciona en el versículo 22: "Y dijo Yahve Dios: ¡Resulta que el hombre ha venido a ser como uno de nosotros en cuanto a conocer el bien y el mal! Ahora pues cuidado, no alargue su mano y tome también del árbol de la vida y comiendo de él viva para siempre" (Génesis, 3:22, Nueva Jerusalén, revisada y aumentada). Peterson pretende reconocer estos dos árboles entre los numerosos árboles representados en los frescos de Malinalco. Identifica como "árbol de la vida" a un zapote blanco, representado con su tronco, hojas y frutos. situado en el muro este, a la izquierda del monograma de la orden agustina. Sustenta su hipótesis en el hecho de que este árbol tenía un importante significado medicinal y ritual para los "aztecas" debido a las propiedades narcóticas de sus hojas, corteza y semillas, y que los españoles lo describieron como un manzano; y como "árbol de la sabiduría" a un árbol con características fantásticas, situado entre los escudos dedicados a los monogramas de Jesús y de María, que tiene enrollado en su tronco a una serpiente "que está hipnotizando" a un gorrión, conjunto que, según ella, es un símbolo cristiano de la tentación demoniaca al alma humana (Figura 11). Adicionalmente, Peterson atribuye a distintas especies de plantas y animales simbolismos religiosos. Afirma que el venado que se encuentra al pie del que considera "árbol de la sabiduría" simboliza la virtud en conflicto con el vicio, representado por la serpiente; asegura que la presencia de dos monos, en el mismo muro este, personifica el vicio, lo que según ella refuerza la idea que se trata del paraíso terrenal porque se relacionan con la tentación que tuvo Adán; sostiene que la garza significa la lealtad y vigilancia a la que estaban obligados los frailes; y el delfín, como rey de los peces, representa al mismo Cristo. Identifica a la granada y a la vid como símbolos de la vida fértil que proviene de la fe cristiana, en este mundo y en el más allá. Las flores significan el ciclo de la vida humana y, las plantas en general, la necesidad de salvarse y el deber de los frailes de seguir los votos a los que estaban comprometidos (Peterson, 1993, pp. 130-131). 
La anterior interpretación suscita muchas dudas. En primer lugar, en el arte medieval y renacentista no se representa el árbol de la vida, solo el de la sabiduría, aquel del que comieron Adán y Eva; incluso los cuatro ejemplos que cita Peterson son poco elocuentes al respecto. El grabado de 1521 de Ludolphus de Sajonia contiene dos árboles, pero estos no tienen ninguna connotación específica, ya que lo que se representa es el ingreso de Adán y Eva al paraíso terrenal guiados por Dios. En el grabado de 1510 perteneciente a la obra Suma de todas las crónicas del mundo solo se representa el "árbol de la sabiduría". La composición del frontispicio de la obra Fior di Virtú no se refiere al paraíso terrenal sino a las flores como símbolo de las virtudes cristianas. La representación de Adán y Eva de Erhard Altdorfer incluye tres árboles sin que esté claro que se trata de los que nos ocupan. Sin embargo, aun aceptando la idea de que ambos árboles estuvieran representados en los murales malinalquenses, cabría cuestionar el hecho de que quienes idearon el proyecto hayan elegido un zapote como árbol de la vida y no una especie europea. Tal cosa se justificaría si los murales estuvieran dedicados a los indígenas y se hubiera optado porque todas las especies representadas fueran nativas. Pero, como quedó asentado en páginas anteriores, abundan las plantas europeas, entre ellas los acantos (la especie más representada), y también hay uvas y rosas, entre otras. Más cuestionable aún resulta la identificación del árbol con la serpiente, con el de la sabiduría. Si bien la serpiente podría interpretarse como la bíblica, el árbol carece de la fruta prohibida que lo caracteriza en todas las representaciones del paraíso terrenal.

Para identificar certeramente lo representado como paraíso terrenal se requeriría, por lo menos, de la presencia de Adán y Eva. Además, como fue habitual en las representaciones medievales y renacentistas europeas, así como en la pintura novohispana del siglo XVI, podría incluir a Dios Padre y el árbol del bien y el mal en forma de manzano con abundantes frutos. Las tres de las imágenes medievales que utiliza Peterson para fundamentar su tesis contienen precisamente estos elementos (Peterson, 1993, pp. 128-131). Un buen ejemplo del ámbito novohispano que pertenece a la misma época en que se pintaron los murales de Malinalco es el frontispicio de la capilla abierta del convento agustino de San Nicolás Tolentino de Actopan, que sí cuenta con los elementos señalados (Mc Dannell y Lang, 2001, pp. 264-267; Wobeser, 2015, pp. 86-93).

Además, Peterson sugiere otras posibles interpretaciones que son excluyentes a la idea de que lo representado sea el paraíso terrenal. Con base en que la concepción de los murales deriva de tapices flamencos de verdure y millefleurs, sugiere que se trata de un hortus conclusus (jardín cerrado) que en la pintura medieval simbolizaba la virginidad de María. Asimismo, relaciona los frescos con los jardines de tradición árabe del sur de España (Peterson, 1993, p. 132). Explora el posible significado que los murales tuvieron para los indígenas y llega a la conclusión de que unas abejas y mariposas, realizadas 
a la usanza prehispánica, pintadas en las bóvedas, son una llave para entender que para ellos lo representado significaba un lugar celestial situado en el más allá, dado que representan los espíritus de los muertos retornando a la tierra (pp. 134-135). Para asociar los murales a una idea escatológica indígena, Peterson parte de la postura sostenida por Manuel Toussaint, y seguida por muchos historiadores del arte, de que la originalidad del arte indocristiano consiste en que fue elaborado por manos indígenas y que estas le imprimieron un sello cultural propio y, ciertamente, esta es una de las razones por la cual muchas obras artísticas producidas en Nueva España se diferencian de las europeas (Bargellini, 2004, pp. 79-91). Si partimos del hecho de que todas o la mayor parte de las pinturas del claustro de Malinalco fueron realizadas por indígenas y que en las áreas menos importantes, como las bóvedas, tuvieron mayor libertad para expresarse, no resulta extraño que se adviertan ciertas formas que recuerdan figuras prehispánicas. Sin embargo, esto no implica que los murales puedan interpretarse como una recreación del más allá prehispánico como pretende Peterson. En primer lugar, es casi seguro que los pintores que participaron en la obra fueron indios ya cristianizados. Desde 1533, año en que los agustinos fundaron el convento de Ocuituco, hubo presencia de frailes evangelizadores en la zona y los murales datan del último tercio del siglo XVI. Es decir, entre los inicios de la expansión del cristianismo en la zona y la factura de los murales median unos 40 años. Además, resulta esclarecedora la opinión de Jorge Alberto Manrique quien, al referirse a las implicaciones que la adopción de la cultura hispánica por parte de los indios tuvo para el arte, sostiene que ellos no se propusieron crear formas propias o inventar algo diferente a lo europeo. Atribuye las supuestas "reminiscencias indígenas", que algunos estudiosos han creído detectar en ciertas obras, a una errónea interpretación de los modelos originales o a un deficiente desempeño del oficio y no a una aportación creativa de los nativos (Manrique, 2007, p. 195).

Laura White Olascoaga y Carmen Zepeda Gómez, en El paraíso botánico del convento de Malinalco, sin cuestionarla, retoman la idea de Peterson respecto a que lo figurado es el paraíso terrenal, ya que lo asocian a la idea coloquial de que "el exuberante follaje representado en los muros y bóvedas crea un ambiente sobrecogedor y paradisiaco, que invita a pensar en el mismo Edén" (White y Zepeda, 2005, p. 30). Ellas centran su análisis en la identificación de las variedades vegetales presentes en los murales. En conclusión, en los mencionados trabajos no hay bases para reconocer en lo representado a alguno de los dos paraísos que formaban parte del imaginario cristiano en la época en que fueron pintados los murales. 


\section{El significado de las especies vegetales y animales representadas en los murales malinalquenses}

Entre las principales preocupaciones de Peterson, White y Zepeda estuvo indagar el significado que los motivos florales y zoomorfos tuvieron dentro de la composición de los murales que nos ocupan. Partieron de la hipótesis de que los murales fueron realizados por indígenas y que ellos incluyeron determinadas especies porque les eran significativas. Para lograr su cometido se dieron a la tarea de identificar las plantas y animales representados en los murales.

Esto fue una tarea muy difícil porque la mayoría de las plantas no están representadas de manera naturalista. A modo de la pintura de grutescos, emergen árboles de los arbustos de acantos o salen de la nada; hay ramas con hojas y flores que no concuerdan entre sí; árboles que a la vez dan uvas, zapotes y rosas; chirimoyas que nacen de plantas de acanto y no están acompañadas de las hojas que les corresponden; frutos de cacao que surgen de las puntas de las ramas y no del tronco; y delgadas ramas que se convierten en poderosos árboles, entre otras incongruencias biológicas (Figuras 11 y 15). Además, las variedades que parecen más apegadas a la realidad carecen de algunos elementos que les son propias, lo que establece una marcada diferencia de la rigurosidad con que fueron representadas en los catálogos botánicos de la época, como el Códice Cruz Badiano; además de que no están pintados a escala.

Figura 15. Águila devorando una serpiente en el mural este. Convento de la Transfiguración de Malinalco

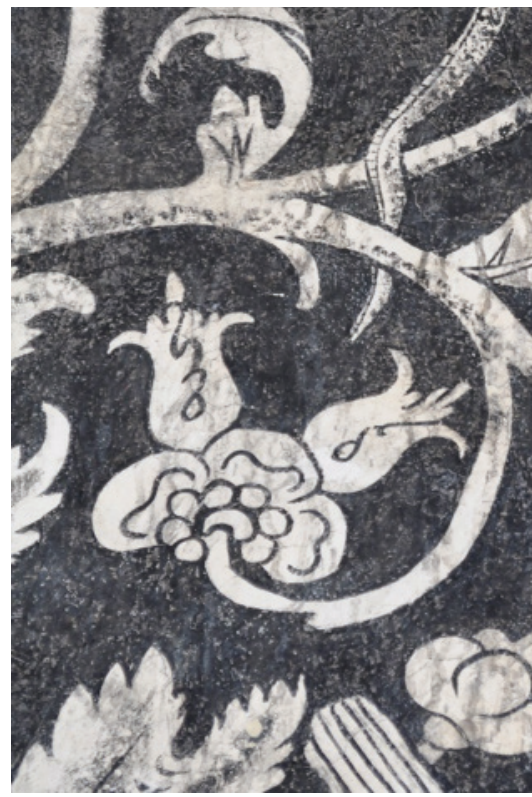

Fuente: von Wobeser, 2017. 
A pesar de estas dificultades taxonómicas, Peterson relacionó 24 plantas y varios animales, entre ellos conejos, monos, pájaros colibríes, patos, gansos, tlacuaches, serpientes, palomas y búhos, con especies que existen realmente (Peterson, 1993, pp. 92-117). White y Zepeda (2005), por su parte, ampliaron el número de especies vegetales identificables a 33, consignaron su nombre científico, así como los nombres castellanos y nahuas con que son conocidos actualmente, y determinaron sus usos medicinales, tanto en el periodo prehispánico, como en la actualidad. Entre las variedades botánicas identificadas por algunas de sus propiedades, generalmente por las flores, están las siguientes: dalia, ninfa (estrella de agua), manzanilla, frijol, cacao, cacaloxóchitl (flor de mayo), cempaxúchitl (flor de muerto), girasol, pasionaria, cabeza de culebra, anona, magnolia, chilillo, cardo, flor de manita, malinalli (zacate), piña, flor de tigre, manto blanco, órgano, nopal, tule (espadaña), trompetilla grande (clarín), zapote blanco, guayabo, cabellín, vid, flor de corazón, cebolleja, acanto y rosa. (White y Zepeda, 2005, pp. 46-111). Sin embargo, las especies identificadas solo representan un porcentaje pequeño de la vegetación plasmada en los muros, el resto son creaciones fantásticas. A partir del grupo de plantas y animales identificado, las autoras se propusieron demostrar que los indios pintores las incluyeron porque eran significativas culturalmente para ellos. White y Zepeda encontraron que la mayoría de ellas tuvo y sigue teniendo en la actualidad propiedades medicinales, por lo que concluyeron que eran importantes culturalmente para los indígenas que intervinieron en la realización de los murales.

Si bien merece reconocerse el gran esfuerzo realizado por las tres autoras mencionadas, sus conclusiones no resultan convincentes. Si la intención de los pintores hubiera sido representar plantas medicinales no se justificaría la inclusión de plantas puramente ornamentales, ni las "fantásticas", ni de los animales que pueblan la naturaleza representada. Si se hubiera querido destacar plantas culturalmente importantes para los indígenas, seguramente hubieran incluido al maíz, la planta que por antonomasia define a la cultura indígena. También faltarían el chile, el frijol y el jaguar; este último considerado sagrado por las culturas nativas. Por su parte, una planta como el cacao, que sin duda era muy importante para la cultura indígena, no se representa de manera naturalista, ya que sus frutos emanan de la punta de las ramas y no del tronco, como debiera ser. Tampoco resulta convincente el significado ritual para el catolicismo que Peterson asignó a las variedades europeas como la uva y la rosa.

La falta de escrupulosidad en la representación de los motivos fitomorfos y zoomorfos, así como la inclusión de especies europeas y americanas, permite concluir que la finalidad perseguida por quienes diseñaron el programa iconográfico de Malinalco no fue hacer un catálogo de plantas y animales, ni explorar sus propiedades. A manera de comparación cabe citar dos obras de la época que sí persiguieron tal fin y que, por ende, incluyen dibujos naturalistas de las plantas reseñadas en ellos. Se trata de Libellus de medicinalibus indorum 
herbis (conocido como Códice Cruz Badiano), escrito en 1552 por el médico indígena Martín de la Cruz y traducido al latín por Juan Badiano, y de la obra de Francisco Hernández sobre la flora americana, quien, como protomédico de la Corona Española, escribió de 38 volúmenes de descripciones verbales y dibujos puntuales de plantas y animales, acompañados de una extensa colección de plantas disecadas.

\section{Un nuevo intento de interpretación del programa iconográfico de los murales}

Entre el tupido follaje de los frescos del claustro bajo de Malinalco destacan los mencionados escudos monumentales con los monogramas de Jesús, María y el emblema de la orden agustiniana (tres en cada uno de los muros). Si bien este tipo de escudos emblemáticos se encuentra en todos los conventos agustinos de la época (Ocuituco, Totolapan, Acolman, Epazoyucan, Tlayacapan y Actopan, entre otros), y en el propio convento de Malinalco aparecen esculpidos en piedra encima de la portería, no es habitual que su tamaño sea colosal ni que ocupen un lugar central en el discurso visual (Figuras de la 1 a la 4).

Considero que es en torno a estos escudos que se desarrolla el programa iconográfico diseñado por los agustinos para su convento y que la vegetación que los circunda tiene una importancia secundaria. Parto de la hipótesis, sostenida por Peterson y por Gerlero, de que la principal fuente visual para los murales fue algún tapiz flamenco. En los tapices flamencos las escenas bíblicas, pastoriles, cortesanas o de cacería, así como los emblemas familiares, se rodeaban de motivos fitomorfos y zoomorfos, mismos que llegaban a ocupar una gran parte del área compositiva. Muy populares eran los géneros conocidos como verdure y millefleurs, cuyos motivos son estereotipados y muy repetitivos. La función de los motivos naturales en estos tapices es ornamental y recreativa. En Malinalco la proporción entre el área que ocupan los escudos y la vegetación que los circunda es similar a los mencionados tapetes, es decir, el espacio pictórico que ocupan los escudos es mucho menor al de la naturaleza que los rodea. La diferencia entre ambos es que mientras en los tapices los motivos zoomorfos y fitomorfos son pequeños y discretos y, por lo tanto, no opacan visualmente a los escudos de armas, en Malinalco la naturaleza cobra una dimensión propia y visualmente predomina sobre los escudos, por lo cual algunos estudiosos le han dado más importancia que los emblemas. White y Zepeda no los toman en cuenta y Peterson apenas les dedica dos páginas de su extensa obra (Peterson, 1993, pp. 149-151). Si bien reconoce su importancia, los interpreta principalmente como símbolos del poder político que los frailes desempeñaron en la conformación de la Nueva España en el siglo XVI y sostiene que el simbolismo heráldico expresado en ellos se refleja en los nexos existentes entre los frailes y la corona española (Peterson, 1993, pp. 150-151). 
Quien sí ha reconocido la importancia a los mencionados escudos es Elena Isabel Estrada de Gerlero. En el artículo "El nombre y su morada. Los monogramas de los nombres sagrados en el arte de la nueva y primitiva Iglesia de las Indias" (2000), sostiene que a los santos nombres de Jesús y de María les adjudicaron un significado mnemónico, evocativo y místico dentro del catolicismo y que desempeñaron un papel importante en el pensamiento y la práctica religiosa de su tiempo. Según Estrada de Gerlero (2000, pp. 182 y 179): "la tradición judía de la cábala subraya que la Torah, en su totalidad, se concentra en la potencia de los nombres de Dios... omnipresentes exaltaciones del Nombre divino ocurren a lo largo del Antiguo y del Nuevo Testamento, por lo cual esta continua alabanza culmina en el Apocalipsis de san Juan" y que estos se asociaban a la buena muerte que conducía a la salvación de las almas en el más allá. Aclara que, dentro de la orden de los agustinos, la veneración de los sagrados nombres se impulsó durante la presidencia del general Egidio de Viterbo (1507-1519), cabalista cristiano, hebraísta y joaquinista, quien fue delegado apostólico por España ante la Santa Sede, y continuó bajo la de su discípulo Jerónimo Seripando, quien presidió la orden, entre 1539 y 1551, y asistió como delegado al Concilio de Trento (Estrada de Gerlero, 2000, p. 184). Ellos propagaron la idea de que detrás de algunos números y letras sagrados existe un simbolismo, a través del cual podía accederse a Dios. En 1530, Clemente VII incluyó la devoción a los santos nombres en la liturgia (Estrada de Gerlero, 2000, p. 198).

La mencionada devoción a los sagrados nombres conjugaba bien con la Iglesia mesiánica que pretendían edificar los frailes agustinos en Nueva España, por lo que convirtieron los nombres de Jesús y de María en el eje de su doctrina. Con el afán de cobijarse bajo ellos y de difundir su culto, bautizaron su provincia de México, así como una escuela para estudios avanzados adjunta a su convento de ese mismo lugar, como 'Dulce Nombre de Jesús'; en 1537, fundaron una cofradía llamada "Santo Nombre de Jesús" (Saranyana y Alejos Grau, 1999, p. 809; Estrada de Gerlero, 2000, p. 190).

La preminencia de los santos nombres dentro de la orden agustina justifica que en Malinalco constituyan el eje del programa iconográfico del claustro bajo. Los motivos naturales que la acompañan parecen haber desempeñado un lugar secundario y, con base en la idea de que la fuente para los murales fueron los tapices, puede concluirse que su finalidad fue ornamental y recreativa. Llenar áreas "vacías" o secundarias con motivos geométricos, fitomorfos, zoomorfos, querubines o animales fantásticos fue una solución que los agustinos del siglo XVI utilizaron habitualmente en la pintura mural de sus conventos. Así, por ejemplo, en la capilla abierta y en el refectorio de Actopan hay casetones, basados en los diseños propuestos por Sebastiano Serlio. En la celda del prior de ese mismo convento aparece un escudo de la orden, rodeado de elementos vegetales. En Tlayacapan abundan los motivos florales en forma de cenefas y de casetones en el templo, la portería, la sala de profundis y 
los claustros alto y bajo; y en varios conventos, como el mismo Tlayacapan, hay balaustradas. En Malinalco, la función ornamental resulta indiscutible en las cenefas de grutescos, tomadas de modelos europeos, y cuyas figuras estereotipadas remiten a plantas y animales fantásticos; en los adornos florales de los escudos y de las letras del salmo, y en las numerosas flores, tallos y hojas que forman parte de los monogramas y en la balaustrada, entre otros. Menos evidente es el propósito ornamental en la exuberante vegetación de la franja central que acompaña a los escudos, ya que los motivos vegetales y animales que la componen son muy variados y no obedecen a ninguna calca ni están tomados de una sola fuente.

Pero, al margen de lo ornamental, la naturaleza pudo haber tenido otros significados para quienes idearon su contenido, para los frailes que habitaron el convento y para los pintores que llevaron a cabo la obra. Desafortunadamente no contamos con las fuentes necesarias que nos permitan dar respuestas certeras a estas inquietudes y el hecho de que Malinalco sea el único convento novohispano en el que los motivos paisajísticos sean tan preponderantes, dificulta aún más la interpretación.

Una clave que ayuda a la interpretación de los murales es el mencionado fragmento del salmo 84 que aparece en el friso epigráfico. Los frailes agustinos que determinaron el programa mural de Malinalco y los que convivieron con las pinturas en años posteriores, debieron haber percibido la naturaleza como un camino para llegar a Dios y una forma de alabarlo como sumo creador del universo. Un señalamiento en este sentido se encuentra en la obra contemporánea Historia natural y moral de las Indias en que se tratan las cosas notables del cielo, elementos, metales, plantas y animales dellas y los ritos, ceremonias, leyes y gobierno de los indios, del jesuita José de Acosta, editada en 1590. Acosta considera que "Toda historia natural es de suyo agradable y, a quien tiene consideración algo más levantada, es también provechosa” (1962 [1590], p. 87). Plantea que acercarse a la naturaleza con un interés científico es válido, pero constituye una mera curiosidad, sin importancia ni utilidad. Para él la vía de acercamiento más elevada es la espiritual, es decir percibir en las cosas naturales al "Sumo y Primer Artífice de todas estas maravillas" y gozar "de su saber y grandeza" (Acosta, 1962 [1590], p. 87). Considera que esto es "excelente teología" y plantea que el mejor medio para ponerla en práctica es mediante los salmos. Y precisamente el salmo 84, incluido en la cenefa superior de los murales, se refiere a la alabanza de Dios en la frase inicial: "Mi corazón y mi carne cantan al Dios vivo", y reitera en la última: "Perpetuamente te alabarán". En este nivel espiritual, resultaba irrelevante que la mayoría de las especies vegetales que acompañan los escudos con sus monogramas sean fantásticas.

La necesidad de alabar a Dios se relaciona con la preocupación en torno a la salvación eterna de las almas, que constituye el eje del pensamiento católico de la época. El salmo alude a esta aspiración: "Aun el gorrión haya casa y la golondrina nido para sí, donde pongan sus polluelos. Entre tus altares, o 
Jehová de los ejércitos, Rey mío y Dios mío, bienaventurados los que habitan en tu casa". La representación de la muerte con su guadaña, junto al fraile del confesionario, recuerda la fragilidad de la vida y de la necesidad de prepararse para obtener una "buena muerte" (Figura 9). La invocación del nombre de Jesús apela a su divina gracia, sin la cual se creía imposible lograr la salvación eterna, y el de María alude al poder de intercesión que se le concedía.

En conclusión, las interpretaciones clásicas realizadas en el siglo pasado sobre lo representado en los murales del claustro bajo del convento de Malinalco requieren una revisión, ya que no son consistentes en cuanto a sus planteamientos. Se necesitan nuevos estudios, basados en fuentes de primera mano, así como un ejercicio comparativo con los programas murales de otros conventos agustinos. Asimismo, sería importante relacionar los murales con la pintura mural de otras partes del convento, particularmente con aquellas que provienen de la misma época y se encuentran en el refectorio, la sacristía y la sala de profundis, de la cual actualmente solo quedan algunos fragmentos en mal estado de conservación.

\section{Referencias}

Acosta, Joseph de. (1962 [1590]). Historia natural y moral de las Indias en que se tratan las cosas notables del cielo, elementos, metales, plantas y animales dellas y los ritos, ceremonias, leyes y gobierno de los indios. O'Gorman, Edmundo (Ed.), México: Fondo de Cultura Económica.

Ángeles Jiménez, Pedro. (2004). Apeles y tlacuilos: Marcos Griego y la pintura cristiano indígena del siglo XVI en Nueva España. En C. Gutiérrez Arriola y M. Maquívar, (Eds.), De arquitectura, pintura y otras artes. Homenaje a Elisa Vargas/ugo. (pp. 119-120). México: Universidad Nacional Autónoma de México.

Bargellini, Clara. (2004). Originality and Invention in the Painting of New Spain. En D. Pierce, R. Ruiz Gomar, F. J. Mayer y C. Bargellini (Eds.). Painting a New World. Mexican Art and Live. 1521-1821. (pp. 79-91). University of Texas Press.

de Capoa, Chiara. (2003). Los diccionarios de arte. Episodios y personajes del antiguo Testamento. Juan Carlos Gentile Vitale, Milán: Electa.

Delumeau, Jean. (2003). Historia del paraíso (S. Ugalde Quintana, tr.). México: Taurus.

Estrada de Gerlero, Elena Isabel. (2000). El nombre y su morada. Los monogramas de los nombres sagrados en el arte de la nueva y primitiva Iglesia de las Indias. En Elisa Vargaslugo (Ed.), Parábola Novohispana. Cristo en el arte virreinal. (pp. 177-203). México: Comisión de Arte Sacro de la Arquidiócesis Primada de México, Fomento Cultural Banamex y Grupo Infra. 
Estrada de Gerlero, Elena Isabel. (1981). El sentido simbólico-litúrgico en los murales del claustro del convento agustino de la Purificación y San Simón de Malinalco. Anuario de Estudios Americanos, 38, 567-598.

Hernández, Francisco. (1615). Cuatro libros de la naturaleza. México: Viuda de Diego López Dávalos.

Manrique, Jorge Alberto. (2007). Una visión del arte y de la historia. (Vol. 3). México: Universidad Nacional Autónoma de México.

Mc. Dannell, Colleen y Lang, Bernhard. (2001). Historia del Cielo. De los autores bíblicos hasta nuestros días. (J. A. Moreno Tortuero, tr.). Madrid: Taurus, Alfaguara S. A.

de Mendieta, Gerónimo. (1770). Historia eclesiástica indiana. México: Antigua Librería Portal de Agustinos.

Nueva Biblia de Jerusalén, revisada y aumentada. (1998). Bilbao: Descleé de Brouwer.

Peterson, Jeanette Favrot. (1993). The paradise garden murals of Malinalco. Utopia and empire in sixteenth-century Mexico. Austin: University of Texas Press.

Pineda Servín, Luis. (7 de marzo de 2018). El convento de Malinalco. La influencia de las restauraciones en la historiografía del claustro. Recuperado de https://www.researchgate.net/.../Luis_Pineda_Servin/...convento_de_ Malinalco

Saranyana, José Ignacio y Alejos Grau, Carmen. (1999). Teología en América Latina. Madrid: Iberoamericana, Vervuert.

White Olascoaga, Laura y Zepeda Gómez, Carmen. (2005). El paraíso botánico del convento de Malinalco, Estado de México. Toluca, Estado de México: Universidad Autónoma del Estado de México.

von Wobeser, Gisela. (2015). Cielo, infierno y purgatorio durante el virreinato de la Nueva España. México: Universidad Nacional Autónoma de México, Estampa Artes Gráficas, Editorial de Otro Tipo. 